\title{
Joubert syndrome and related disorders: a paradigm to understand splitting and lumping in ciliopathies
}

\author{
EM Valente
}

\author{
From First International Cilia in Development and Disease Scientific Conference (2012) \\ London, UK. 16-18 May 2012
}

Joubert syndrome and related disorders are autosomal recessive or X-linked ciliopathies characterized by a complex midbrain-hindbrain malformation (the Molar Tooth Sign), consisting of vermis dysplasia, a deepened interpeduncular fossa, and thickened, elongated and mal-orientated superior cerebellar peduncles. Common clinical features include hypotonia, ataxia, psychomotor delay, oculomotor apraxia and neonatal breathing dysregulation, variably associated with multiorgan involvement, mainly of the eyes, kidneys and liver. Other central nervous system malformations, polydactyly, and laterality defects may also be present. Genetic heterogeneity mirrors the clinical heterogeneity of JSRD. Over 17 genes have been identified, all encoding for proteins of the primary cilium, with intriguing allelic series and clinical correlations that have made these conditions a paradigmatic example of "splitting and lumping" in human genetics. Indeed, the same phenotype can be caused by mutations in distinct genes, and conversely the same gene can be responsible of distinct ciliopathies, such as JSRD, nephronophthisis, Senior-Loken, Bardet-Biedl and Meckel syndromes. Of note, there is clinical heterogeneity even within families, with affected siblings discordant for features such as encephalocele or retinal involvement. This extreme phenotypic variability associated with mutations in one and the same gene remains a main open question. An intriguing explanation has implicated an oligogenic model of inheritance (already demonstrated for BardetBiedl syndrome and other ciliopathies), in which mutations, rare variants and even polymorphisms at distinct loci epistatically interplay to modulate the ciliopathy phenotype. To date, mutation analyses of most JSRD-

Correspondence: e.valente@css-mendel.it

Neurogenetics Unit, CSS-Mendel Institute, Rome, Italy causative genes have not been performed in large cohorts, and the systematic genetic screening of multiple ciliopathy genes remains a still unmet need to address the complexity of JSRD genetics.

Published: 16 November 2012

doi:10.1186/2046-2530-1-S1-O27

Cite this article as: Valente: Joubert syndrome and related disorders: a paradigm to understand splitting and lumping in ciliopathies. Cilia 2012 1(Suppl 1):O27.

Submit your next manuscript to BioMed Central and take full advantage of:

- Convenient online submission

- Thorough peer review

- No space constraints or color figure charges

- Immediate publication on acceptance

- Inclusion in PubMed, CAS, Scopus and Google Scholar

- Research which is freely available for redistribution 